\title{
FFAR4 Gene
}

National Cancer Institute

\section{Source}

National Cancer Institute. FFAR4 Gene. NCI Thesaurus. Code C92546.

This gene plays a role in fatty acid binding and glucagon-like peptide 1 secretion. 